\title{
DIABASE VARIATION AND GENESIS
}

\author{
WALter W. BOYD, JR.
}

Boyd, Walter W., Jr. 1972: Diabase vatiation and genesis. Bull. Geol. Soc. Finland 44, 21-34.

\begin{abstract}
The uniformity of diabase composition has been interpeted as evidence o their having undergone a minimum of modification at low pressures and indicative of derivation from an homogenous source.

Comparison of diabase analyses with experimentally investigated basaltic compositions in a data projection scheme suggests, contrary to this veiw, that the diabases have undergone extensive near surface fractionation.

This conclusion suggests that the similarity of trace element abundances is due to a pervasive leveling by the fractionating phases in a low pressure regime.

Walter W. Boyd, Jr., Grant Institute of Geology, West Mains Road; Edinburgh E $H$ 9; $3 \mathrm{JW}$, United Kingdom.
\end{abstract}

\section{Introduction}

Both Turner and Verhoogan (1960) and Philpotts and Schnetzler (1968) have stressed the chemical and petrographic uniformity of diabases from widely differing localities and geological ages. Philpotts and Schnetzler ascribe this uniformity to ». . . either limited partial fusion or almost complete fusion of similar source materials . . .» and ». . . rapid transfer from depth of magmas with near liquidus temperatures . . .».

The same reasoning was applied earlier to the chemically analogous tholeite basalts. Their uniformity of composition has been taken as evidence of their "primitiveness» (Turner and Verhoogan, 1960). O’Hara (1965; 1968), however, has argued that few basalts are erupted at the surface without having undergone extensive fractionation after their derivation from a mantle source rock. The essence of his argument lies in several assumptions:

(1) the source rock in the mantle, from which the basalts (and diabases) are derived by partial fusion is a garnet lherzolite (olivine-orthopyroxene-clinopyroxene-garnet). Recent studies of the distribution of nodule compositions (Mathias et al.; 1969) in kimberlites support this assumption; volumetrically, the idealized composition would contain: $64 \%$ olivine $\left(\mathrm{Fo}_{88}-{ }_{94}\right) ; 27 \%$ orthopyroxene $\left(\mathrm{Of}_{1.5}-{ }_{11}\right) ; 3 \%$ chrome diopside and $6 \%$ of a pyrope rich garnet. The residua from the partial fusion would be, at most pres- 
sures, a garnet harzburgite (olivine-orthopyroxene-garnet), a composition which is again abundant in kimberlite nodules.

(2) Melting, under conditions simulating those in the mantle, of anhydrous peridotites (Cohen et al., 1967; O'Hara and Yoder, 1967; Green and Ringwood, 1968) and interpetation of these data show that partial fusion, to any extent, of peridotites proposed as mantle source rocks, will yield liquids very different in composition from those of the great majority of erupted basalts. This difference leads to the conclusion that the great majority of basaltic rocks do not represent primitive or primary magmas.

(3) The primary liquid yielded by the partial fusion of garnet lherzolite is modified, more or less continuously, by fractionation of a solid phase or phases throughout its ascent to the surface.

One may not agree with O'Hara's choice of a four phase lherzolite as the source rock of basaltic magmas; Green and Ringwood (1968) do not, and construct "pyrolite» out of one part "primitive" basalt to three parts "depleted" mantle. The resultant composition, in the zone of magma generation, is that of a three phase lherzolite. The solid residua (lherzolitic) and liquids produced upon partial fusion have been criticized by O'Hara (1970) as not being abundant in kimberlite nodules or capable of producing liquids in equilibrium with the commonly observed cumulates in basalts or the sequence of phases appearing in most basalts.

The solid residua and liquids produced by the partial fusion of proposed and more, or less, widely accepted mantle analogues are discussed by O'Hara (1970) in detail. Diabase genesis is discussed in the present study utilizing O'Hara's proposed mantle model; the main conclusions, however, are concerned with low pressure modifications to the parental diabase magma, whatever composition its ultimate source may be. Partial fusion of the source rock has been assumed to have occured in the upper mantle (implying, for the continental areas, pressures greater than ten kilobars); fusion at shallower depths implies very steep thermal gradients. Locally, such gradients do exist, i.e., at the mid-ocean ridges, but are not considered typical for the provenance of continental diabases.

It is not generally appreciated that the amount of liquid produced by the partial fusion of a garnet lherzolite (or any peridotite) is not a linear function of the amount of heat supplied; the significance of this, however, can be appreciated in any discussion of enrichment factors and trace element ratios as fusion proceeds (see figure 8, O'Hara, 1968). Obviously, the concentrations of the wincompatible» elements $(\mathrm{Rb}$, $\mathrm{Sr}, \mathrm{Th}, \mathrm{U}, \mathrm{Pb}, \mathrm{Zr}, \mathrm{Ba}$ ) are critically dependant on the degree of partial fusion in the initial stages of melting. Thus, the lack of variance in the abundances of various trace elements from different diabase dikes, for instance, would not be, in itself, a reliable criteria for limited partial fusion of similar source materials (Philpotts and Schnetzler, 1968).

The original intent of the present study was to note the wider implications of some new analyses made of two diabase dikes, at Vehkajärvi (Finland) and Fiskartorp (Sweden). The work of Laitakri (1969) on the Häme diabases suggested at least part of the fractionation sequence followed in the evolution of those particular diabases. The chemical similarity of diabases allowed the inclusion of other well described groups in suggesting a more general scheme of evolution.

\section{Outline of methods and projections used}

In common with many types of variation diagrams, the method used in this paper attempts to show the evolution of magmas. To this end, the phase equilibria within chemical systems which are approximations to natural systems are used. The advantage of the projections used here over standard variation diagrams is that as well as utilizing a greater proportion of the com- 
ponents of the rocks discussed, they have a predicative property, i.e., one can predict the sequence of phases and phases involved in deriving hypothetical differentiates from a supposed parent. In conjunction with a least-squares program such as that of Wright and Doherty (1970), the amount of the individual phases can be predicted as well.

By grouping cations with similar affinities in basic and ultrabasic rocks, O'Hara (1968) reduced ten major and minor oxides to four components in order to facilitate direct comparisons with phase equilibria in the synthetic system $\mathrm{CaO}-\mathrm{MgO}-\mathrm{Al}_{2} \mathrm{O}_{3}-\mathrm{SiO}_{2}$. This modified system was termed CMAS, in which the four apeces of the quadrilateral used to represent the system are:

$\mathrm{C}=$ (Molecular proportion $\mathrm{CaO}-3.3 \mathrm{P}_{2} \mathrm{O}_{5}+$ $\left.2 \mathrm{Na}_{2} \mathrm{O}+2 \mathrm{~K}_{2} \mathrm{O}\right) 56.08$

$\mathrm{M}=$ (Molecular proportion $\mathrm{FeO}+\mathrm{MnO}+$ $\left.\mathrm{NiO}+\mathrm{MgO}-\mathrm{TiO}_{2}\right) 40.31$

$\mathrm{A}=$ (Molecular proportion $\mathrm{Al}_{2} \mathrm{O}_{3}+\mathrm{Cr}_{2} \mathrm{O}_{3}$ $\left.+\mathrm{Fe}_{2} \mathrm{O}_{3}+\mathrm{Na}_{2} \mathrm{O}+\mathrm{K}_{2} \mathrm{O}+\mathrm{TiO}_{2}\right) 101.96$

$\mathrm{S}=$ (Molecular proportion $\mathrm{SiO}_{2}-2 \mathrm{Na}_{2} \mathrm{O}-$ $\left.2 \mathrm{~K}_{2} \mathrm{O}\right) 60.09$

„CMAS» was reserved for synthetic samples, mineral mixtures and some experimentally investigated ultrabasic rocks. Jamieson (1970), used the same schema to fix the one atmosphere phase boundaries of melted natural basalts from Tilley et al (1966), and designated the apeces $\mathrm{XO} \cdot \mathrm{YO} \cdot \mathrm{R}_{2} \mathrm{O}_{3} \cdot \mathrm{ZO}_{2}$ in place of CMAS. Both are given on the figures used in this paper.

The present scheme of deriving partial phase equilibria diagrams has distinct advantages over the use of CIPW normative minerals in data projection schemes:

(1) It portrays silica saturated and undersaturated phase equilibria together, over the range of pressures involved in basalt (and diabase) genesis

(2) It includes almost all of the major minerals of basic and ultrabasic rocks. Projections to and from a large number of minerals into a variety of planes within the quadrilateral are easily made. Minerals and rocks of the same total $\mathrm{Fe}$ and $\mathrm{Mg}$ contents but of varying $\mathrm{Fe} / \mathrm{Mg}$ ratios plot in the same position, c.f. olivine, clinopyroxene but not orthopyroxene.

It also has distinct disadvantages; an increase in $\mathrm{Na}_{2} \mathrm{O}, \mathrm{K}_{2} \mathrm{O}, \mathrm{TiO}_{2}$ and $\mathrm{Fe}_{2} \mathrm{O}_{3}$, for instance, causes a shift in the projected position of cotectic equilibria (Jamieson, 1970) which is especially noticeable in the olivine projection (Figure 1). This is, of course, critical in evaluating the evolution of residual liquids in olivine basalt $\rightarrow$ hawaiite $\rightarrow$ mugearite genesis where such liquids are enriched in just these components as plagioclase is fractionated. The effect, certainly real, but primarily inherent in the method used to calculate the projection parameters, causes the projected position of the cotectic equilibria to migrate towards $\mathrm{A}\left(\mathrm{R}_{2} \mathrm{O}_{3}\right)$. Thus, with an increase in the residual liquids of the alkalis, $\mathrm{TiO}_{2}$, and $\mathrm{Fe}_{2} \mathrm{O}_{3}$, the liquid compositions move in the predicated fashion along the cotectic line, which itself is continuously migrating towards $\mathrm{A}\left(\mathrm{R}_{2} \mathrm{O}_{3}\right)$.

The migration of the phase boundaries for equilibria in several groups of basalts is shown in Figure 1; it can be seen that the shape of the phase volumes remains (within the uncertainty of the data used to construct the boundaries) essentially the same.

Projection from (or towards) a particular phase assumes that phase to be present ideally as the first phase on the liquidus, but in practice it may be the second phase to appear without causing distortion in the diagrams. The position of the idealized solid phases, omitting solid solution, is shown in the insets accompanying each figure. Projections from olivine (Figure 1), clinopyroxene - $>$ cpx»- (Figure 2) and plagioclase (Figure 3) onto the stippled planes of the insets are used in the present paper.

Within all of the planes used the boundaries for the phase volumes are nearly perpendicular to the surface of the plane. Uncertainty as to 
OLIVINE PROJECTION

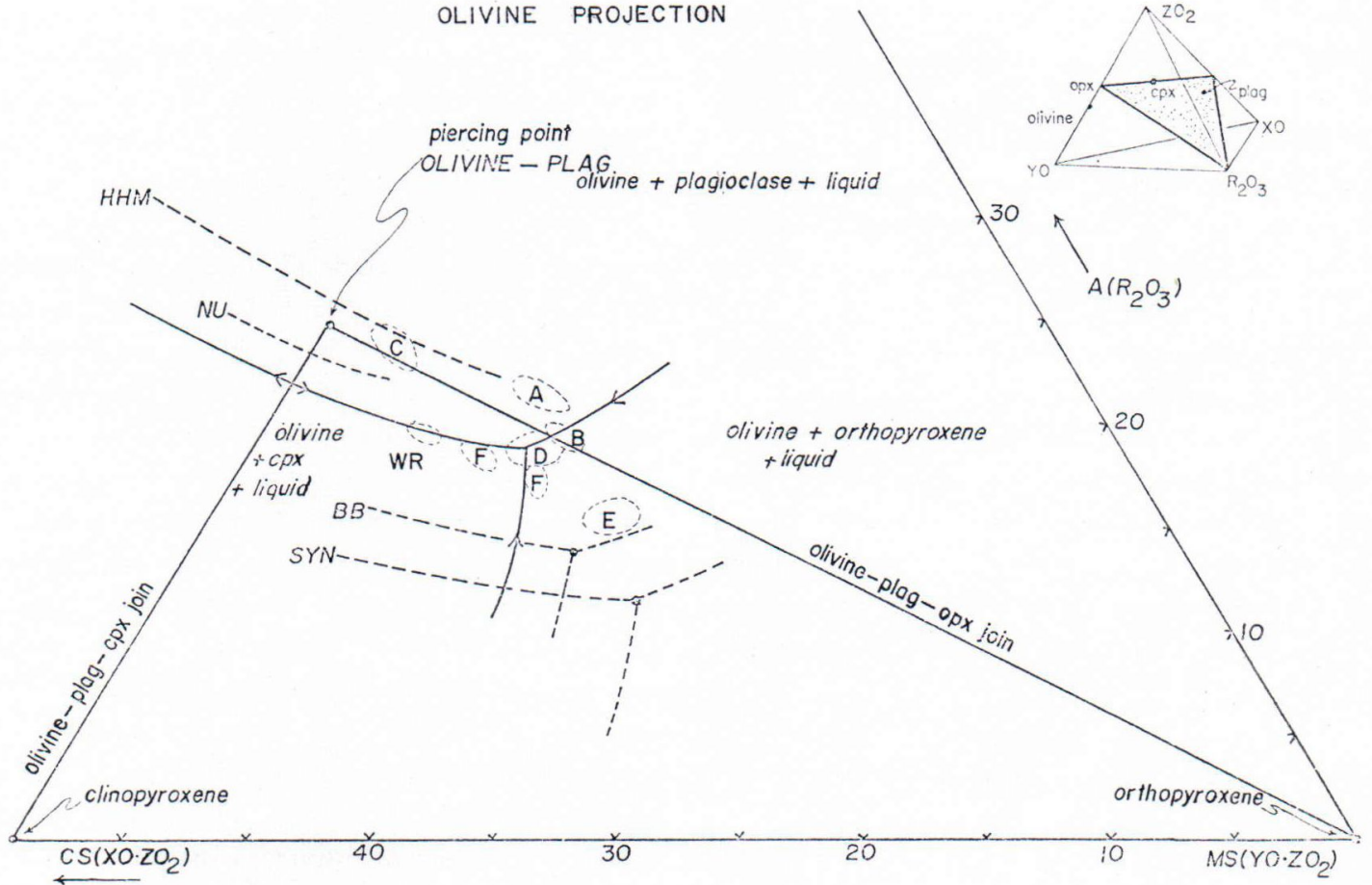

Fig. 1. Olivine projection.

The position of the cotectic curves is taken from Jamieson (1969), except for the alkalibasalt-hawaiite -mugearite curves, which are based on the melted rock data of Tilley et al. (1966). Ideally, in the melted rocks, olivine will be the first to appear; the next phase to appear determines into which of the three areas the projected analysis will fall. If the second and third phases appear within say, $20^{\circ}$ of each other, then the position of the projected cotectic line (or rather "zone») dividing the respective fields of the second and third phases can be plotted with some confidence.

One projection alone is not sufficient to determine in which phase volume the projected analyses lies; for instance, assuming the applicability of the solid curves (based on Hawaiian tholeites), field E (Antarctic) diabases lies in either the olivine or orthopyroxene phase volumes (or the surface between them) and it is only by viewing this group from clinopyroxene that it can be seen that the group of analyses do indeed lie in the olivine field albeit very close to the olivine-orthopyroxene interface.

The solid lines mark the cotectic boundaries drawn primarily on the basis of Hawaiian melted tholeites (Jamieson, 1970). The synthetic boundaries (dashed with the label SYN), Nuanetsi (NU) and Hebridean hawaiitemugearite (HHM) are from Jamieson (1970) and Boyd (unpublished) and the Baffin Bay (BB) from Clark (1970).

The olivine-plagioclase-clinopyroxene join is a thermal divide at pressures less than 8-10 kilobars (O'Hara, 1968). The Olivine-plagioclase piercing point is the point at which the cotectic line joining olivineplagioclase pierces the plane of the projection.

The diagrams are read as follows, using $\mathrm{E}$ as an example: once it is known that $\mathrm{E}$ lies in the olivine phase volume then the sequence of phases appearing as pheno- crysts will be olivine, then orthopyroxene followed by clinopyroxene and later joined by plagioclase at the invariant point where the three cotectic lines meet.

The analyses of the various diabase groups are denoted as follows: Vehkajärvi (A); Fiskartorp (B); Ansio and Satakunta (C); Wyoming PreCambrian (D); Antarctic (E); eastern North America "parental» (WR) and »daughter» $(\mathrm{F})$, and Tasmania (G).

The position of the synthetic 5 kilobar cotectic curves lies in the area shown as "olivine + plagioclase + liquid", not too far from the area marked as »C». It is not known how far from this position the natural boundaries would lie, but it has been assumed that their position would still be in the molivine + plagioclase + liquid" area, above the olivine - plag-opx join. If, for instance, the diabases were evolved from a peridotite source rock in the mantle, at pressures greater than or equal to ten kilobars and reached equilibrium with the three to four phases commonly present in their chilled margins, then they would lie somewhere in the vicinity of the area marked as $\gg \mathrm{C} »$ - or further to the left, for equilibration at higher pressures. O'Hara (1970), Figure 5) shows the migration of the (pseudo) invariant point with pressure for the synthetic system, and it has been assumed here that the natural systems follow similar paths.

The projected position of the Vehkajärvi analyses (A) and the presence of plagioclase alone as a phenocryst indicates that the liquid lay in the plagioclase phase volume and had equilibrated at some pressure greater than one atmosphere. The positions of »E» and »G» suggest the possibility that yet another set of cotectic curves lying between $" \mathrm{BB}$ » and the Hawaiian curves may have been more applicable. 


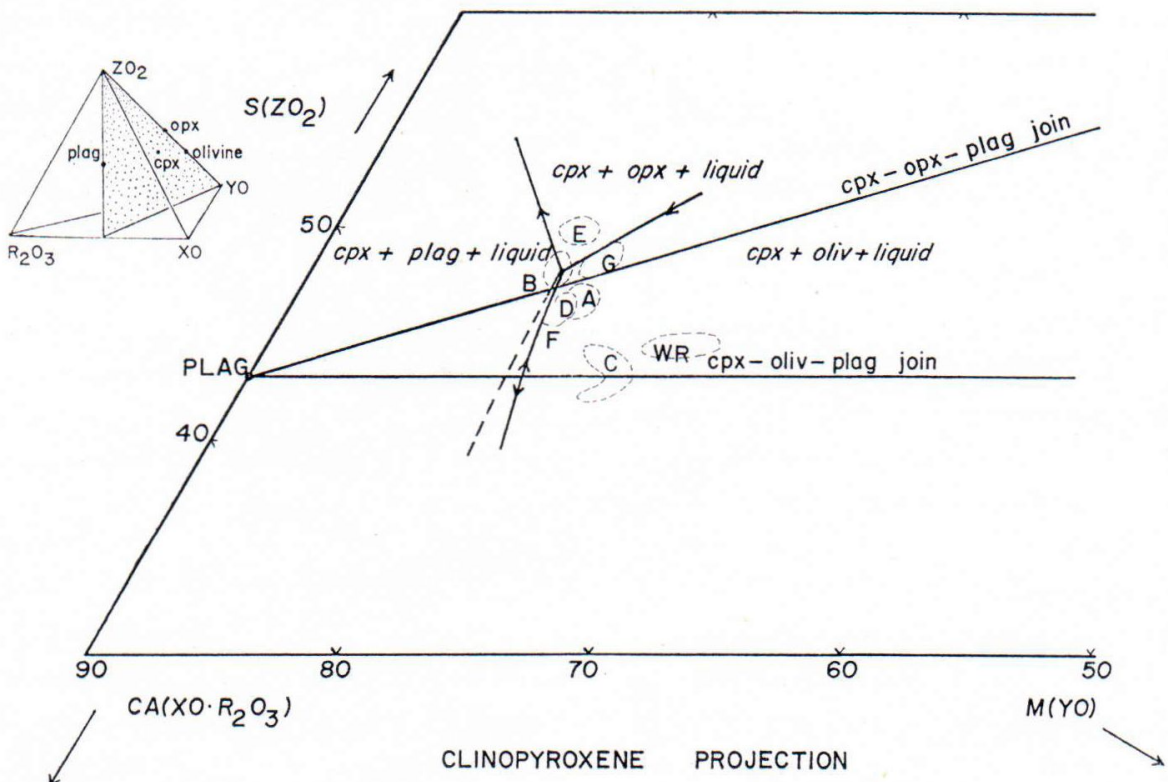

Fig. 2. Projection from clinopyroxene

The notation is the same as in Figure 1. The phase boundaries for synthetic compositions and Nuanetsi are not shown simply because they lie so close to the boundaries derived from the melted Hawaiian tholeites. The shift towards the "PLAG» composition point is very marked for rocks evolving in the alkalibasalt-hawaiite - mugearite clan, and the progressive shifts are shown by dashed lines to the left of the solid boundaries.

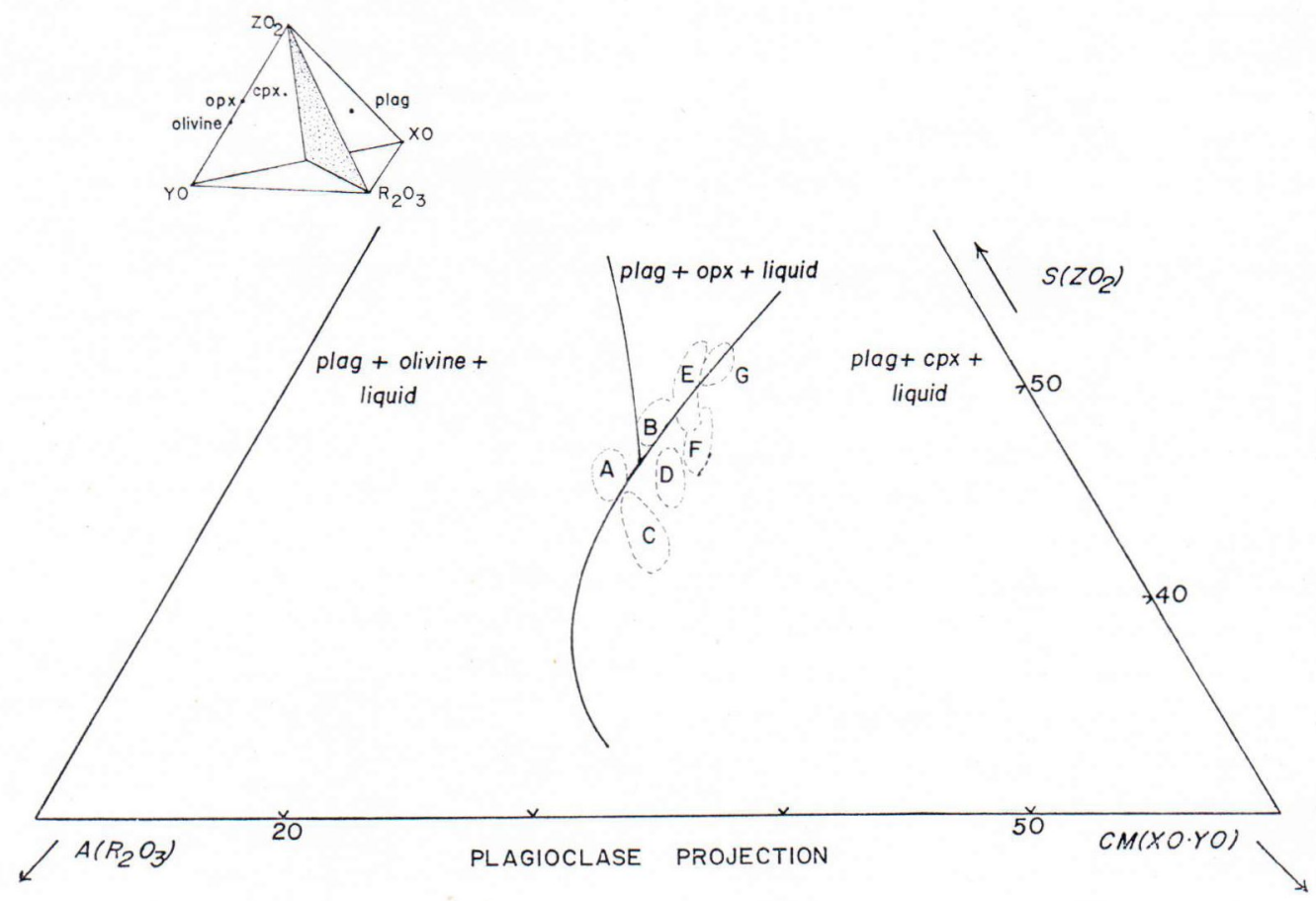

Fig. 3 Plagioclase Projection

The boundaries here are not well defined due primarily to the proximity of the projection point to the plane of projection (see its position in Figure 2). It does supplement the other two diagrams and is of value only where plagioclase is either the first or second phase to appear on the liquidus. As the An content of the normative plagioclase increases, the boundaries shift to the right. 
the phase boundaries might arise if this were not so, and the phase volumes were divided by planes lying at a shallow angle to the lower surface of the phase volume from or to which one projected. In the plagioclase projection (Figure 3) the blurring of the cotectic line between olivine and clinopyroxene on the lower face of the plagioclase phase volume is probably due to the proximity of the cotectic line to the point from which analyses are being projected, and not inclination of the clinopyroxene and olivine phase volume interfaces to the lower surface of the plagioclase volume.

The rocks projected into these diagrams must be chemically analogous to the melted rocks used in constructing the boundaries. In using the data from melted basalts to construct the phase equilibria in a particular projection, as noted above, the phase from which (or towards which) one projects should be the first phase on the liquids. This is not always possible, and so, even when it occurs as the second phase, it has been used in the compilation, apparently without distortion. The method is described in more detail in the caption to Figure 1.

This present study emphasizes first the essential similarity of continental diabases, and secondly their resemblance to liquid compositions which have equilibrated, at low pressures, with three or four phases.

\section{Petrological descriptions of the diabases}

The petrologic descriptions of the diabases at Vehkajärvi and Fiskartorp are syntheses of the descriptions by Laitakari (1969) and Gorbatshev (1961) respectively, with minor additions. The descriptions are more detailed than those given to the other groups because specimens were available for examination, and for the most part their features are common to many of the diabase groups.

\section{The Vebkajärvi Dike}

The only phenocrysts noted are plagioclase megacrysts with cores of $\mathrm{An}_{58} \pm_{2}$ enclosed in a narrow rim of $A_{n_{2}} \pm_{3}$ and an outer rim of $\mathrm{An}_{52} \pm_{2}$. The Häme diabases, in general, carry similar phenocrysts; their groundmass assemblages are zoned plagioclase $\left(\mathrm{An}_{45}-{ }_{63}\right)$, clinopyroxene (both titanaugite and pigeonite), olivine, separate ilmenite rods and spongy titanomagnetite possibly being replaced by pyrrhotite (and rare chalcopyrite). Biotite, alkali feldspar and acicular apatites occur as accessory minerals (Laitakari, 1969). Only one radiometric date exists for Häme diabases - 1700 m.y., or roughly Jotnian age.

\section{The Fiskartorp Dike}

Gorbatshev (1961) described the Jotnian (?) porphyritic diabases south of Eskilstuna as containing $25-40 \%$ plagioclase phenocrysts and pseudomorphs after olivine, or rarely, unaltered olivine phenocrysts.

In the dike analyzed, trending WSW of Fiskartorp, the plagioclase phenocrysts are strongly zoned from $\mathrm{An}_{60}-{ }_{65}$ (cores) to rims of $\mathrm{An}_{55}-{ }_{60}$. The cores are, for the most part, altered to sericite. The groundmass titanaugite is altered on the borders to chlorite and has rods (exsolution?) of an opaque mineral (rutile?). The opaque minerals are maghemite and ilmenite. Olivine pseudomorphs are now chlorite(s) plus maghemite. The groundmass is primarily plagioclase (with sericite) and clinopyroxene with chlorite(s).

Both dike analyses have been recast in "chemical modes» by the least squares program of Wright and Doherty (1970), and are given in Table 3. Although no optical modes were made of the dikes, the »chemical modes» are analogous to optical modes of other dikes in the respective groups.

In both dikes the plagioclase megacrysts show little evidence of resorption, which is interpeted as evidence of equilibration with the magma, as represented by the groundmass analyses.

The majority of the nodules found in the Häme diabases have plagioclase $\left(\mathrm{An}_{48}-{ }_{53}\right)$, hypersthene and rarely olivine (Laitakari, 1969). Cor- 
TABLE 1

\begin{tabular}{|c|c|c|c|c|c|c|c|c|c|c|c|}
\hline & 1 & 2 & 3 & 4 & 5 & 6 & 7 & 8 & 9 & 10 & 11 \\
\hline $\mathrm{SiO}_{2} \ldots \ldots$ & 49.5 & 50.1 & 49.7 & 49.6 & 49.5 & 52.9 & 53.2 & 52.8 & 52.4 & 50.4 & - \\
\hline $\mathrm{Al}_{2} \mathrm{O}_{3} \ldots$ & 14.5 & 14.3 & 14.6 & 14.3 & 14.5 & 12.9 & 12.8 & 13.8 & 13.4 & 16.5 & - \\
\hline $\mathrm{Fe}_{2} \mathrm{O}_{3} \ldots$ & 1.16 & 1.99 & 1.90 & 2.10 & 2.16 & 2.88 & 2.93 & 3.71 & 3.21 & 1.50 & - \\
\hline $\mathrm{FeO} \ldots .$. & 12.91 & 12.62 & 12.56 & 12.40 & 12.20 & 12.75 & 12.40 & 11.78 & 11.90 & 11.12 & - \\
\hline $\mathrm{MgO} \ldots$ & 3.7 & 4.0 & 3.8 & 4.1 & 3.9 & 3.0 & 3.2 & 3.6 & 3.8 & 4.2 & - \\
\hline $\mathrm{CaO} \ldots .$. & 6.8 & 6.8 & 6.8 & 6.9 & 7.1 & 7.0 & 6.9 & 7.0 & 7.4 & 7.8 & - \\
\hline $\mathrm{Na}_{2} \mathrm{O} \ldots$ & 3.00 & 2.71 & 2.62 & 2.61 & 2.58 & 2.92 & 2.81 & 2.92 & 2.92 & 2.95 & - \\
\hline $\mathrm{K}_{2} \mathrm{O} \ldots$. & 1.90 & 1.88 & 2.48 & 1.91 & 1.82 & 2.13 & 2.12 & 1.98 & 1.76 & 1.76 & - \\
\hline $\mathrm{H}_{2}^{2} \mathrm{O}^{+} \ldots$ & 1.67 & 1.49 & 1.51 & 1.51 & 1.37 & 0.54 & 0.67 & 0.65 & 0.69 & 1.11 & - \\
\hline $\mathrm{CO}_{2} \ldots \ldots$ & 0.6 & 0.5 & 0.5 & 0.6 & 0.6 & - & - & - & - & - & - \\
\hline $\mathrm{TiO}_{2} \ldots$ & 2.65 & 2.93 & 2.95 & 2.78 & 2.89 & 2.35 & 2.36 & 2.22 & 2.16 & 2.20 & - \\
\hline $\mathrm{P}_{2} \mathrm{O}_{5} \ldots \ldots$ & 0.8 & 0.8 & 0.9 & 0.8 & 0.8 & 0.5 & 0.4 & 0.4 & 0.4 & 0.3 & - \\
\hline $\mathrm{MnO} \ldots$ & 0.17 & 0.18 & 0.22 & 0.19 & 0.25 & 0.22 & 0.22 & 0.23 & 0.21 & 0.18 & - \\
\hline Total & 100.1 & 100.3 & 100.6 & 99.7 & 99.6 & 100.1 & 100.1 & 100.4 & 100.1 & 99.9 & - \\
\hline $\mathrm{Cu} \ldots \ldots$ & 30 & 31 & 30 & 29 & 30 & 33 & 29 & 29 & 38 & 30 & 35 \\
\hline $\mathrm{Ba} \ldots \ldots$ & 1064 & 997 & 832 & 937 & 973 & 930 & 881 & 839 & 825 & 810 & 796 \\
\hline $\mathrm{Zr} \ldots \ldots$ & 343 & 343 & 338 & 344 & 344 & 228 & 221 & 204 & 197 & 164 & 160 \\
\hline Y $\ldots$ & 53 & 55 & 51 & 49 & 53 & 59 & 58 & 56 & 52 & 50 & 43 \\
\hline $\mathrm{Sr} \ldots$ & 336 & 339 & 341 & 342 & 339 & 165 & 170 & 176 & 188 & 260 & 181 \\
\hline $\mathrm{Rb}$. & 56 & 60 & 62 & 67 & 61 & 56 & 54 & 49 & 49 & 40 & 49 \\
\hline $\mathrm{Zn} \ldots \ldots$ & 190 & 157 & 161 & 264 & 176 & 157 & 140 & 140 & 134 & 115 & 131 \\
\hline $\mathrm{Pb} \ldots \ldots$ & 5 & 7 & 5 & 4 & 8 & - & - & - & - & - & - \\
\hline $\mathrm{La} \ldots .$. & 24 & 42 & 48 & 43 & 40 & - & - & - & - & - & 一 \\
\hline $\mathrm{Ce} \ldots \ldots$ & 84 & 66 & 98 & 98 & 91 & - & - & - & 一 & - & - \\
\hline $\mathrm{Ga} \ldots \ldots$ & 16 & 17 & 15 & 16 & 16 & - & - & - & 一 & - & - \\
\hline
\end{tabular}

The Vehkajärvi Dike

1. V-7; contact on east side of dike.

2. V-1; $69 \mathrm{~cm}$ from east side of dike.

3. V-15. $132 \mathrm{~cm}$ from east side of dike.

4. V-6;200 $\mathrm{cm}$ from east side of dike.

5. V-9;220 $\mathrm{cm}$ from east side of dike.

The Fiskartorp Dike

6. B-1; contact

7. B-2; $150 \mathrm{~cm}$ from contact, towards dike center.

8 . $\mathrm{B}-3 ; 150 \mathrm{~cm}$ from contact, towards dike center; south of $\mathrm{B}-2$.

9. B-4; $250 \mathrm{~cm}$ from contact, towards dike center.

10. B-5; whole rock, porphyritic, with $10 \%$ plagioclase phenocrysts.

11. trace element content of separated groundmass.

roded hypersthene phenocrysts (interpeted as evidence of non-equilibration with the magma) are present in both the Häme diabases and the diabase at Keuruu (Marmo and Mikkola, 1963). Laitakari also noted one peridotite nodule in the Häme diabases.

Gorbatshev (1961) found "glomeroporphyrites» in dikes to the west of the Fiskartorp dike containing plagioclase $\left(\mathrm{An}_{69}-{ }_{73}\right)$, clinopyroxene and olivine, and suggested a direct genetic connection between the olivine dolerites and the quartz normative diabases in the suite of Jotnian and sub-Jotnian diabases.

The phases occurring as phenocrysts in the other diabases considered in the section on Petrogenesis and utilized in the projections are briefly described below.
Edwards (1942) in the diabases of Tasmania noted that in the chilled borders, phenocrysts of plagioclase $\left(A n_{70}\right)$, clinopyroxene and orthopyroxene occurred. The orthopyroxene phenocrysts usually had rims of clinopyroxene; rarely, as at Mt. Sedgewick, small corroded olivine phenocrysts had narrow rims of a "pyroxene».

A generalized description of the Antarctic diabase sills (Hamilton, 1965) gives four phases as possible phenocrysts: plagioclase $\left(\mathrm{An}_{65}\right)$, augite, pigeonite and an orthopyroxene.

Microphenocrysts in the contact diabase of the Red Hill dike (McDougall, 1964) consist of orthopyroxene (bronzite), less commonly plagioclase $\left(\mathrm{An}_{85}\right)$ and augite.

No phenocrysts are noted in the descriptions of the diabases in North Carolina (Ragland et al., 
TABLE 2

Molecular norms of compositions in Table 1

\begin{tabular}{r|r|r|r|r|r|r|r|r|r|r}
\hline & 1 & 2 & 3 & 4 & 5 & 6 & 7 & 8 & 9 & 10 \\
\hline Qtz $\ldots \ldots$ & 0.13 & 2.7 & 0.98 & 2.4 & 3.0 & 5.0 & 6.1 & 5.3 & 4.6 & 0.0 \\
Or $\ldots \ldots$ & 11.6 & 11.3 & 14.9 & 11.6 & 11.0 & 12.7 & 12.6 & 11.7 & 10.5 & 10.5 \\
$\mathrm{Ab} \ldots \ldots$ & 26.2 & 23.3 & 22.5 & 22.6 & 22.4 & 25.0 & 23.9 & 24.8 & 24.9 & 25.2 \\
$\mathrm{An} \ldots \ldots$ & 20.8 & 21.5 & 21.1 & 22.2 & 23.1 & 15.9 & 16.2 & 16.9 & 18.4 & 26.9 \\
$\mathrm{Hy} \ldots \ldots$ & 24.9 & 24.4 & 23.8 & 24.2 & 23.2 & 18.9 & 18.4 & 18.1 & 19.1 & 19.7 \\
$\mathrm{Di} \ldots \ldots$ & 7.6 & 6.2 & 6.1 & 6.7 & 6.7 & 13.4 & 13.0 & 12.5 & 12.8 & 8.6 \\
$\mathrm{Ol} \ldots \ldots$ & 0.0 & 0.0 & 0.0 & 0.0 & 0.0 & 0.0 & 0.0 & 0.0 & 0.0 & 2.0 \\
$\mathrm{Mt} \ldots \ldots$ & 1.7 & 2.9 & 2.8 & 3.1 & 3.2 & 3.3 & 4.3 & 5.4 & 4.7 & 2.2 \\
$\mathrm{Il} \ldots \ldots$ & 5.2 & 5.7 & 5.7 & 5.4 & 5.6 & 4.5 & 4.5 & 4.2 & 4.1 & 4.2 \\
Ap $\ldots \ldots$ & 1.9 & 1.9 & 2.2 & 1.8 & 1.8 & 1.2 & 1.0 & 1.0 & 0.9 & 0.7
\end{tabular}

\section{Analytical notes.}

All the major oxides, except $\mathrm{Na}_{2} \mathrm{O}, \mathrm{H}_{2} \mathrm{O}$, and $\mathrm{FeO}$, were determined on a Phillips PW 1212 automatic X-ray fluorescence unit using pressed discs. The sample, lanthanum oxide and lithium tetraborate were mixed in the ratio 1: $1: 8$, and fused at $1050^{\circ} \mathrm{C}$; the glass bead was ground to approximately -200 mesh in a tungsten carbide ball mill. This powder was dried, pressed with a backing of boric acid powder at 15 tons pressure, and used for the analyses. On the basis of replicate analyses and the analyses of twelve to fifteen international standards the error of the major elements is estimated to be: $\mathrm{SiO}_{2}= \pm 0.35 ; \mathrm{Al}_{2} \mathrm{O}_{3}= \pm 0.4 ; \Sigma \mathrm{Fe}$ as $\mathrm{Fe}_{2} \mathrm{O}_{3}$ $= \pm 0.2 ; \mathrm{CaO}= \pm 0.2 ; \mathrm{MgO}= \pm 0.4 ; \mathrm{TiO}= \pm 0.2 ;$ $\mathrm{P}_{2} \mathrm{O}_{5}= \pm 0.2 ; \quad \mathrm{MnO}= \pm 0.05 ; \overline{\mathrm{K}}_{2} \mathrm{O}= \pm 0.2$.

$\mathrm{Na}_{2} \mathrm{O}$, and checks on $\mathrm{K}_{2} \mathrm{O}$, were done using an EEL flame photometer. The error here is estimated to be \pm 0.15 .

$\mathrm{FeO}$ was determined by a modified Wilson procedure. The sample plus ammonium vanadate was broken down by addition of cold HF and allowed to stand for at least three days to ensure completion of the process. The P.T.F.E. crucible was placed in a beaker of dilute boric acid, $\mathrm{H}_{2} \mathrm{SO}_{4}$ was added to adjust the $\mathrm{pH}$, and

1968), but in the zone next to the chilled margins, phenocrysts of plagioclase and less frequently augite or olivine. No petrographic descriptions were given in the later paper (Weigand and Ragland, 1970).

The lower contact of the Palisades sill in the Englewood section contains microphenocrysts of plagioclase $\left(\mathrm{An}_{66}\right)$, corroded olivine $\left(\mathrm{Fo}_{79}-_{82}\right)$ which may be surrounded by a reaction rim of orthopyroxene, augite with slightly resorbed borders and occasional orthopyroxenes. Up to half of the three percent, total of phenocrysts could be olivine (Walker, 1969). a redox indicator (orthophosphoric acid with $\mathrm{Na-di-}$ phenylamine $\varrho$ sulphonate), then titrated with ferrous ammonium sulphate dissolved in $\mathrm{H}_{2} \mathrm{SO}_{4}$.

The error, based only on replicate sample analysis, is estimated to be \pm 0.15 .

$\mathrm{H}_{2} \mathrm{O}+$ was determined by the method of Peck (1964) ${ }^{1}$ using 1 gram of sample mixed with 3 grams of flux (lead chromate) heated in a test tube for 3 to 5 minutes and then rewighing the filter paper placed near the end of the stoppered tube. Precision was \pm 0.15 ; the total error is believed to be less than \pm 0.2 .

$\mathrm{CO}_{2}$ was determined by analyzing for total $\mathrm{C}$, then analyzing for $\mathrm{CO}_{2}$, and determining the difference, if any. The sample was heated in the presence of oxygen to $1700^{\circ} \mathrm{C}$ in a Leco induction furnace. The gas volume was measured, then the gas was passed through potassium hydroxide, then the volume measured again, the difference indicating the amount of $\mathrm{C}$ present. For $\mathrm{CO}_{2}$, the same procedure was followed, adding $2 \mathrm{~N}$ HCI to sample, plus ferrous sulphate to prevent oxidation. Accuracy is estimated as $\pm 1 \%$ (relative).

1 Peck, L. C. (1964) Systematic Analysis of Silicates. U.S.G.S. Bulletin 1170 .

\section{Petrogenesis}

The projections (Figures 1, 2 and 3) emphasize the essential similarity of the various diabase groups. Most of the projected analyses lie close to the locus (cotectic line) of liquids in equilibrium with plagioclase, olivine and clinopyroxene at one atmosphere pressure. This group includes the Vehkajärvi, Fiskartorp, Keuruu, Antarctic (Gunn, 1966; Hamilton 1965), eastern United States (Weigand and Ragland, 1970), Wyoming (Condie et al., 1969; Prinz, 1964) diabases. A smaller group, including the Ansio and Satakunta diabases (Finnish), "parential» composi- 
TABLE 3

Representative modes of the diabases at Vehkajärvi and Fiskartorp, using the mineral analyses published in Laitakari (1969) in the least squares program of Wright and Doherty (1970)

\begin{tabular}{l|c|c|c|c|c|c}
\hline & \multicolumn{5}{|c|}{ Percentage of mineral present and composition } \\
\cline { 2 - 5 } & Plagioclase & Augite & $\begin{array}{c}\text { Olivine } \\
\left(\mathrm{Fo}_{35}\right)\end{array}$ & $\begin{array}{c}\text { Magne- } \\
\text { tite- } \\
\text { Ilmenite }\end{array}$ & Apatite & Chlorite \\
\hline $\begin{array}{r}\text { Vehka- } \\
\text { järvi }\end{array}$ & $63 \% ; \mathrm{An}_{52}$ & 7.2 & 16.6 & 8.0 & 3.0 & 3.0 \\
$\begin{array}{r}\text { Fiskar- } \\
\text { torp }\end{array}$ & $58 \% ; \mathrm{An}_{\mathbf{4}}$ & 18.5 & 8.7 & 10.0 & 0 & 5.0
\end{tabular}

Derivation by least squares of Weigand and Ragland's "daughter» composition from their proposed "parental» composition, using their estimated mineral compositions and chemical data from Deer, Howie and Zussman's »Rock Forming Minerals», in Wright and Doherty's program

\begin{tabular}{|c|c|c|c|c|c|c|}
\hline & Parent & $\begin{array}{l}\text { Plagio- } \\
\text { clase } \\
\left(\mathrm{An}_{73}\right)\end{array}$ & $\begin{array}{c}\text { Clino- } \\
\text { pyroxene }\end{array}$ & Olivine & Daughter & $\begin{array}{l}\text { Calcu- } \\
\text { lated* }\end{array}$ \\
\hline & 49.31 & 49.38 & 47.18 & 38.26 & 52.56 & 51. \\
\hline $1_{2} \mathrm{O}_{3}$ & 15.76 & 32.17 & 4.64 & 0.94 & 14.13 & 14.7 \\
\hline $\mathrm{e}_{2} \mathrm{O}_{3} \ldots$ & 1.64 & 0.14 & 1.41 & 0.38 & 1.65 & 2.2 \\
\hline $\mathrm{eO} \ldots$. & 9.17 & 0.09 & 8.43 & 22.26 & 9.21 & 9.0 \\
\hline M & 10.18 & 0.06 & 15.52 & 36.46 & 7.66 & 7. \\
\hline 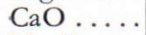 & 10.85 & 14.75 & 19.91 & 1.24 & 10.80 & 11.4 \\
\hline $\mathrm{a}_{2} \mathrm{O}$ & 2.27 & 2.95 & 0.33 & 0.03 & 2.12 & 2.5 \\
\hline $\mathrm{K}_{2} \mathrm{O}$ & 0.40 & 0.17 & 0.18 & 0.02 & 0.77 & 0.5 \\
\hline $\mathrm{H}_{2} \mathrm{O}$ & calcu & ited $\mathrm{v}$ & er fr & & & \\
\hline $\mathrm{TiO}_{2} \ldots$ & 0.47 & 0.02 & 1.11 & 0.08 & 1.14 & 0.63 \\
\hline${ }_{2} \mathrm{O}_{5}$ & not & sed in & & ulation & & \\
\hline Solution: & 100 & -17.1 & -1.8 & -12.8 & 00 & \\
\hline
\end{tabular}

* Calculated signifies the composition of the rock calculated by the program using the proportions given in the solution.

* Solution gives the best fit of the possible amounts needed to derive the daughter composition from the parent composition by subtracting the mineral compositions given as input.

tions in the dikes of eastern North America and some of the Wyoming dikes plot well away from this cotectic line and the main body of the diabase analyses.

There are at least two possible, direct, origins for those quartz normative diabases whose analyses plot close to the one atmosphere equilibrium curve:

(1) derivation by the partial fusion of a peri- dotite source rock at pressure less than 5 kilobars (ca. 15 kilometers) (Boyd et al., 1964).

(2) partial fusion of a peridotite source rock at pressures greater than approximately 20 kilobars (ca. 60 kilometers) to yield a hypersthene normative picrite liquid. Continuous precipitation of olivine during the ascent of the liquid, followed by near surface fractionation of other phases would result in compositions close to the low pressure cotectic curve (O’Hara, 1968).

The second alternative is more probable unless a peridotite or gabbro source in the crust, or a very thin crust with steep geothermal gradients is postulated. There is, on the other hand, little positive evidence for the second alternative. Possibly the lone peridotite nodule in the Häme diabases represents this stage in the evolution of these diabases.

In either scheme, fractionation of the plagioclase + hypersthene \pm olivine nodules in the Häme diabases and the plagioclase megacrysts (or phenocrysts) common to so many diabases will be confined to relatively low pressures.

The presence in these nodules of a plagioclose more sodic than the majority of the plagioclase megacrysts suggests (Cohen et al., 1967) nodule fractionation at slightly greater pressures as does the implied disequilibrium of the hypersthene with the groundmass in the Häme as well as the Keuruu diabases. The plagioclase megacrysts, presumed on morphological evidence to be in equilibrium with the groundmass, have distribution coefficients similar (Table 4) to those for plagioclases of similar composition and believed by Philpotts and Schnetzler (1969) to have equilibrated with their groundmass at low pressures.

Specifically for the diabases in Häme, and presumably Keuruu, equilibration of the magma, at pressures slightly greater than one atmosphere, with plagioclase + hypersthene + olivine would leave the residual liquid in the field of plagioclase or plagioclase + olivine (Figure 1) as the magma moved upwards to equilibrate at 
TABLE 4

Distribution coefflcients for the plagioclases separated from the Vehkajärvi and Fiskartorp diabases, compared with plagioclases of similar composition in Philpotts and Schnetzler (1969). The large discrepancies for Rb and Ba in the Fiskartorp plagioclase are believed to result from the concentration of these elements in the altered, sericite rich cores of the phenocrysts and not from the presence of an alkali feldspar

\begin{tabular}{l|c|c|c|c}
\hline & Plagioclase composition & $\mathrm{D}^{\mathrm{Sr}}$ & $\mathrm{D}^{\mathrm{Rb}}$ & $\mathrm{D}^{\mathrm{Ba}}$ \\
\hline Philpotts and & & & & \\
Schnetzler $\ldots \ldots \ldots$ & $\mathrm{An}_{\mathbf{4 6}}{ }_{50}$ & $2.75-2.84$ & $0.0479-0.138$ & $0.363-0.589$ \\
Vehkajärvi $\ldots \ldots \ldots$ & $\mathrm{An}_{53}$ & 2.63 & 0.115 & 0.329 \\
Fiskartorp $\ldots \ldots \ldots \ldots$ & $\mathrm{An}_{\mathbf{4 8}}$ & 2.62 & 1.33 & 2.68 \\
\hline
\end{tabular}

Unit cell data for the two plagioclases based upon a least squares refinement of bulk sample using the program of Evans, Appleman and Handwerker (1963) ${ }^{1}$. The sample, plus an internal standard of synthetic powdered $\mathrm{CaF}_{2}$ was scanned over the range $13^{\circ} 2 \Theta$ to $50^{\circ} 2 \Theta$ three times and the average of the best defined peak positions was used. The goniometer speed was $0.50^{\circ} 2 \Theta / \mathrm{min}$., the chart speed was $1600 \mathrm{~mm}$./hour

\begin{tabular}{c|c|c|c|c|c|c}
\hline & $\mathrm{A}$ & $\mathrm{B}$ & $\mathrm{C}$ & $\alpha$ & $\beta$ & $\gamma$ \\
\hline Vehkajärvi . & $8.192 \pm .001$ & $12.871 \pm .002$ & $7.118 \pm .001$ & 9320.5 & 11615.2 & 9011.9 \\
Fiskartorp ... & $8.191 \pm .02$ & $12.865 \pm .01$ & $7.110 \pm .01$ & 9330.4 & 11612.1 & 8951.4
\end{tabular}

Volume

Vehkajärvi... $671.6 \quad \AA^{3}$

Fiskartorp ... $670.8 \quad \AA^{3}$

Chemical analyses by the methods explained in analytical notes following Table 2

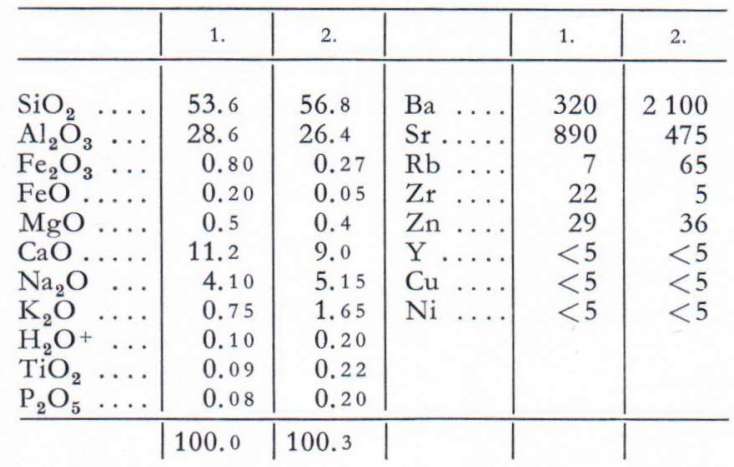

1 Evans, H. T., Jr., Appleman, D. E., Handwerker, D. S. (1963) The least squares refinement of crystal unit cells with powder diffraction data by an automatic computer indexing method (abstr.). Amer. Crystallogr. Assoc., Cambridge, Mass., Ann. Meet., Program, pg. $42-3$.

one atmosphere. It may be that fractionation of the assemblage plagioclase + orthopyroxene + olivine, common in layered intrusions (O'Hara, 1970) and in the chilled margins of many diabases as microphenocrysts, is common to the evolution of many diabases.
There is, however, an equally plausible alternative, based on other phenocryst and nodule (Swedish diabases near Eskilstuna; in particular, the Gastorp dikes) assemblages: plagioclase + clinopyroxene + olivine. Weigand and Ragland (1970) assuming that the olivine rich diabases, 
plotted as WR in Figures 1 and 2 were parental to the quartz normative diabases, proposed a cumulate consisting of $52 \%$ plagioclase $\left(\mathrm{An}_{66}\right)$, $25-30 \%$ olivine $\left(\mathrm{Fo}_{65}\right)$ and $16 \%$ clinopyroxene $\left(\mathrm{Wo}_{52} \mathrm{En}_{35} \mathrm{Fs}_{15}\right.$ ). This extract is modified in their summary on the basis of no europium anomaly in either the Palisades Sill diabase or W-1 (a diabase from Centerville, Virginia). Obviously implicit in this reasoning is the chemical equivalence of diabases. The proposed, more probable, extract, based on the maximum amount of plagioclase $(19 \%)$ that can crystallize and fractionate before a europium anomaly can be detected (Philpotts and Schneitzler, 1968) is given as: olivine $\left(\mathrm{FO}_{87}\right)+$ clinopyroxene $\left(\mathrm{Wo}_{40} \mathrm{En}_{44}\right.$ $F_{16}$ ) in the ratio 7:1 plus plagioclase $\left(A n_{75}\right)$. The compositions of the minerals are closer in the first »extract» to those observed as phenocrysts in the chilled margins of the Antarctic diabases (Hamilton, 1965) and the Palisades sill (Walker, 1969). A least-squares fit of the later, modified extract to the "parent» and »daughter» compositions is poor (Table 3 ), but an alternative solution with a more sodic feldspar and other minor adjustments would give a better fit. What is important, provided one accepted WR as "parental", is the necessity for large amounts of olivine to be removed, compared to clinopyroxene. This suggests, as does Figure 1, that the liquid is well up into the olivine phase volume. The sequence, then, of cumulates would be: olivine, followed by plagioclase + clinopyroxene \pm olivine, plus orthopyroxene at the invariant point. This is a simplified scheme in that it assumes fractionation of extracts to give cumulates in discrete steps whereas the process probably occurs continuously.

From the brief petrographic descriptions given, the majority of diabases described here have been in equilibrium with at least three phases: plagioclase, clinopyroxene and either olivine or orthopyroxene, and in some cases with all four. This is in accord with the positions of the projected analyses and it suggests that the diabases, like most tholeites, are the products of near surface fractionation and for the most part have not reached the surface after »rapid transport from depth» or "at liquidus temperatures» (Philpotts and Schneitzler, 1968).

The reaction relationships noted by Edwards (1942) and Walker (1969), i.e.,

olivine + silica-saturated liquid $\rightarrow$ orthopyroxene and

orthopyroxene + silica-saturated liquid $\rightarrow$ clinopyroxene

are both suppressed at pressures greater than 5 kilobars (O'Hara, 1968).

All the major element chemistry and petrographic evidence suggest, therefore, equilibration at low pressures, with the implied extensive fractionation of phases to bring the residual liquid composition into coincidence with the low pressure cotectic curve.

Not all of the analyses, however, project near the low pressure cotectic curve. Almost all of this second group lie near the thermal divide clinopyroxene-olivine-plagioclase and the ten kilobar cotectic equilibration curve (O'Hara, 1968, pg. 90, figure 6). This would suggest that magma represented by the compositions reached the surface with a minimum of equilibration at low pressures - provided, of course, that they are not cumulus enriched.

The diabases are commonly associated with quartz-normative residua; thus Laitakari (1969) notes the common association of quartz porphery with diabases on the borders of the rapakivi massifs. Walker (1953) described in some detail the granophyres in lenses and schlieren of diabases (Table 5), and Barker and Long (1969) describe the association of a feldspathoidal syenite with quartz diabases. Although the syenite-diabase association is very rare, and is attributed in this instance by Barker and Long to assimilation of adjacent country rock, it is conceivable that the second group of diabases (»Group $C$ » in Figures 1 and 2), had they continued to evolve in the thermal divide, would have syenitic residua rather than granitic. 
TABLE 5

Granophyres and a syenite associated with diabase sills and dikes

\begin{tabular}{|c|c|c|c|c|c|}
\hline & 1 & 2 & 3 & 4 & 5 \\
\hline $\mathrm{SiO}_{2} \ldots$ & 66.02 & 66.80 & 77.50 & 77.35 & 54.68 \\
\hline $\mathrm{Al}_{2} \mathrm{O}_{3} \ldots$ & 11.58 & 12.10 & 11.33 & 11.08 & 21.63 \\
\hline $\mathrm{Fe}_{2} \mathrm{O}_{3} \ldots$ & 5.92 & 0.97 & 1.41 & 1.28 & 2.22 \\
\hline $\mathrm{FeO} \ldots$ & 3.82 & 1.50 & 0.87 & 0.50 & 2.00 \\
\hline $\mathrm{MgO} \ldots$ & 0.44 & 0.50 & 0.32 & 0.22 & 1.25 \\
\hline $\mathrm{CaO} \ldots$ & 3.15 & 2.62 & 0.94 & 0.39 & 2.86 \\
\hline $\mathrm{Na}_{2} \mathrm{O} \ldots$ & 2.73 & 2.40 & 2.58 & 2.84 & 7.03 \\
\hline $\mathrm{K}_{2} \mathrm{O} \ldots$ & 3.13 & 4.20 & 4.43 & 5.42 & 4.58 \\
\hline $\mathrm{TiO}_{2} \quad \ldots$ & 1.00 & 0.18 & 0.13 & 0.19 & 0.79 \\
\hline $\mathrm{P}_{2} \mathrm{O}_{5} \quad \ldots$ & 0.34 & 0.39 & 0.08 & 0.09 & 0.28 \\
\hline $\mathrm{MnO}$ & 0.13 & - & 0.02 & 0.04 & 一 \\
\hline $\mathrm{H}_{2} \mathrm{O}^{+} \ldots$ & 1.01 & 5.75 & 0.70 & 0.37 & 1.88 \\
\hline $\mathrm{H}_{2} \mathrm{O}_{-} \cdot$. & 0.80 & 3.00 & 0.01 & 0.09 & 0.27 \\
\hline Total & 100.07 & 100.30 & 100.32 & 99.86 & 99.97 \\
\hline Norms & & & & & \\
\hline Qtz .... & 32.7 & 33.5 & 43.3 & 39.4 & $12.2(\mathrm{Ne})$ \\
\hline Or $\ldots$ & 18.8 & 27.0 & 26.3 & 32.2 & 27.2 \\
\hline $\mathrm{Ab} \ldots$ & 23.5 & 22.1 & 21.9 & 24.2 & 36.7 \\
\hline An $\ldots$. & 10.3 & 10.7 & 4.2 & 1.4 & 12.5 \\
\hline Di $\ldots .$. & 2.8 & 0.6 & - & - & $2.8(\mathrm{Ol})$ \\
\hline Ну .... & 0.5 & 3.2 & 1.1 & 0.6 & - \\
\hline $\mathrm{Mt} \ldots$. & 8.7 & 1.5 & 2.1 & 1.2 & 3.3 \\
\hline $\mathrm{Il} \ldots . .$. & 1.9 & 0.4 & 0.3 & 0.4 & 1.5 \\
\hline Ap $\ldots$. & 0.8 & 1.0 & 0.2 & 0.2 & 0.7 \\
\hline
\end{tabular}

1. Average of Red Hill granophyre analyses M162, M8, M19, M17.

2. Residual glass in tholeitic diabase, Kinkell, Scotland (quoted from Turner and Verhoogan, 1960; pg. 216. With $\mathrm{BaO} 0.29$.

3. Granite porphery (center of dike). Quoted from Savolahti (1956): The Ahvenisto Massif in Finland. Bull. Comm. Géol. de Finlande No. 174 contains 0.8 normative corundum.

4. Quartz porphery from Åland rapakivi. Quoted from Sederholm (1934). Bull. Comm. Géol. Finlande. Analyses by Lokka; pg. 67. Contains 0.05 corundum and 0.46 haematite as normative minerals.

5. Brookville syenite. Analyst, G. Steiger, 1899. Quoted from Barker and Long (1969). Contains 0.5 normative corundum.

It has been suggested (Laitakari, 1969) that during plagioclase fractionation, the plagioclases rose, rather than sank. The calculated density at near liquidus temperatures (1200?C) for the Vehkajärvi (2.69 grams $\left./ \mathrm{cm}^{3}\right)$ and Fiskartorp (2.68 grams $/ \mathrm{cm}^{3}$ ) diabases (dry) using the methods outlined by Bottinga and Weill (1970) do not suggest this conclusion, as plagioclase $\left(\mathrm{An}_{50}-{ }_{55}\right)$ would range in density from 2.69-2.70 grams/ $\mathrm{cm}^{3}$. With the assumption that the measured water contents approximate the content of water in the magma, the density decreases (2.55 and 2.64 grams $/ \mathrm{cm}^{3}$ respectively), so that one might well wonder why the nodules are present; either the volatile content was very much lower or the ascent of the liquid quite rapid indeed after fractionation of the nodule assemblages.

\section{Trace elements}

As a basic premise, the trace element content of the chilled diabases is a function of:

(a) the composition of the source region and amount of partial fusion occurring there,

(b) crystal fractionation during the ascent of the magma, and at the surface,

(c) vaguely defined mechanisms such as wall rock reaction.

Condie et al. (1969) explained the abundant plagioclase phenocrysts and low $\mathrm{Sr}$ contents in some Wyoming diabases as resulting from partial fusion of a source region rich in $\mathrm{CaO}-\mathrm{Al}_{2} \mathrm{O}_{3}$. No depth was specified but the implication is that of near surface genesis with a peridotite model. It is, on the basis of the previous discussion, not neccessary to do so, especially to account for the plagioclase phenocrysts, a feature common to many other diabases.

The low content of $\mathrm{Sr}(150 \pm 30 \mathrm{ppm})$ is typical of many diabases, as is a general similarity of trace element content. If the diabases were a "primary" magma, one, that is, unmodified since genesis in the source region, the content of trace elements, with the appropriate partition coefficients, would determine the range of trace element content in the source region. The main point of this paper has been that diabases, in general, have undergone extensive low pressure fractionation. If this conclusion is accepted, then the similarity of trace-element content is not neccessarily due to some common genetic processes in a homogenous source region, but due to a pervasive "channeling» of residual com- 
TABLE 6

Trace element contents of recently analyzed diabases and a compilation for quartz normative tholeites, representing 87 to 158 analyses

\begin{tabular}{l|r|r|r|r|r|r|r|r|r|r}
\hline & 1 & 2 & 3 & 4 & 5 & 6 & 7 & 8 & 9 & 10 \\
\hline $\mathrm{Ba}$ & - & - & - & - & - & 320 & 195 & 200 & 180 & 200 \\
$\mathrm{Zr}$ & 58 & 86 & 54 & 53 & 83 & 128 & 120 & 88 & 100 & 100 \\
$\mathrm{Y}$ & - & - & - & - & - & - & 29 & 22 & 25 & 25 \\
$\mathrm{Sr}$. & 131 & 147 & 102 & 100 & 126 & 186 & 175 & 168 & 180 & 400 \\
$\mathrm{Rb}$ & 12 & 23 & 12 & 12 & 30 & 45 & - & 17 & 22 & 5 \\
$\mathrm{Zn}$ & 86 & 98 & 84 & 65 & 99 & - & - & - & 82 & - \\
$\mathrm{Cu}$ & - & - & - & - & - & - & 110 & - & 110 & 125 \\
$\mathrm{Ni}$ & 58 & 32 & 390 & 249 & 85 & 143 & 95 & 70 & 78 & 70
\end{tabular}

1. Connecticut-Pennsylvania diabases (mean of 15 analyses). From Weigand and Ragland (1970).

2. Virginia diabases, quartz normative (mean of 7 analyses). From Weigand and Ragland (1970).

3. Virginia diabases, olivine normative (mean of 7 analyses). From Weigand and Ragland (1970).

4. Ferrar olivine dolerite, chilled margin (Gunn, 1966; No. 26903).

5. Ferrar hypersthene dolerite, chilled margin. (Gunn, 1966; No. 4012). 1969)

6. PreCambrian diabase dikes, Wyoming (Condie et al.,

7. Palisades Sill, chilled base. (Walker, 1969).

8. Average of 17 Karroo diabases (Nockolds and Allen, 1956).

9. W-1; values from: Fleischer, M. J. (1969) U.S. Geological Survey Standards - I.

Additional data on rocks $\mathrm{G}-1$ and $\mathrm{W}-1,1965-67$. Geochimica et Cosmochimica Acta, Vol. 33, pgs. $65-79$.

10. Quartz normative tholeites; median values from: Prinz, M., Geochemistry of basaltic rocks in Basalts, Volume 1; edited by Hess and Poldervaart, 1968.

positions by low pressure fractionation of at least three phases. A small part of this »channeling» may be the result of medium to high pressure fractionation, but since this involves olivine almost alone, a limited number of trace elements are affected.

What little isotopic data is available (Compston et al., 1968) suggests that diabases are not uniform, at least as far as $\mathrm{Sr}^{8} 7 / \mathrm{Sr}^{86}$ ratios are concerned. This leads to the question of whether or not isotope fractionation does occur (as suggested by Pankhurst, 1969) or selective diffusion of isotopes (Compston et al., 1968). There has been little data collected to support one mechanism in preference to another, or that the heterogeneity is not due to the source region itself.
The correlation coefficients of $\mathrm{K}_{2} \mathrm{O}$ with $\mathrm{Rb}$ (0.903), $\mathrm{Zn}$ (0.853), $\mathrm{P}_{2} \mathrm{O}_{5}$ (0.769), Zr (0.786), $\mathrm{TiO}_{2}(0.714)$, i.e., the so called wincompatible» elements, are significant at the $99.9 \%$ level (Fisher, 1958 Table $\mathrm{V}$ a) for the data in Table 6 and Figures 1, 2, 3; this suggests that none of these elements is being removed by fractionating phases in significant amounts. Potassium oxide has been used as a reference to compare other elements with since ideally it is removed by alkali feldspar fractionation, which is not known to have occurred.

There is a lack of correlation between $\mathrm{K}_{2} \mathrm{O}$ and $\mathrm{Sr}$, which suggests removal of $\mathrm{Sr}$ by fractionation of plagioclase. This interpretation might also be valid for $\mathrm{Na}_{2} \mathrm{O}$, but removal of sodium could also be a result of clinopyroxene fractionation (as in, for instance, an earlier episode of eclogite fractionation).

What evidence there is, then, suggests plagioclase fractionation and a lack of extensive $\mathrm{Fe}-\mathrm{Ti}$ oxide fractionation. It supports, but does not validate, the conclusions based on the projections.

\section{Summary and Conclusions}

Projections of the analyses of many diabases into phase equilibria diagrams suggest that most diabases are the products of extensive near surface fractionation, rather than being primitive in any sense. This is also suggested by published descriptions of the chilled mergins which in most cases carry at least three phenocryst phases.

If this conclusion is accepted, then it follows that the similarity of trace element contents is due to near surface fractionation and not indicative of a homogenous source region or the degree of partial fusion in that source region.

Acknowledgements - I wish to thank Dr. K. G. Cox for critically reading the manuscript and suggesting a very large number of possible improvements. My wife Aila and Dr K. R. Gill have helped with specific sections, for which I am very grateful. Messrs M. J. Saunders and G. F. Angell have guided the analytical work and discussed various aspects of it, for which I am also thankfull. 


\section{REFERENCES}

BArker, D. S. and Long, L. E. (1969) Feldspathoidal Syenite in a Quartz Diabase Sill, Brookville, New Jersey. J. Petrol., 10, part 2.

BottingA, Y. and WeIlL, D. F. (1970) Densities of liquid silicate systems calculated from partial molar volumes of oxide components, Amer. J. Sci., 169.

Boyd, F. R., England, J. L. and Davis, B. T. C. (1964) Effects of pressure on the melting and polymorphism of enstatile, $\mathrm{MgSiO}_{3}$. J. Geophys. Res., 69.

Clark, D. B. (1970) Tertiary Basalts of Baffin Bay: Possible Primary Magma from the Mantle. Contrib. Mineral. Petrol., 25.

Cohen, L. H., Ito, K. and Kennedy, G. C. (1967) Melting and phase relations in an anhydrous basalt to 40 kilobars. Amer. J. Sci., 265.

Compston, W., McDougall, I. and Heier, K. S. (1968) Geochemical comparison of the Mesozoic basaltic rocks of Antarctica, South Africa, South America and Tasmania, Geoch. et Cosmochim. Acta, 33.

Condie, K. C. and Barsky, C. K. (1969) Geochemistry of Pre-Cambrian diabase dikes from Wyoming. Geoch. et Cosmochim. Acta, 33.

EDwards, A. B. (1942) Differentation of the dolerites of Tasmania. Journal of Geology, Volume 50, pp. $451-480,579-610$.

Fisher, R. A. (1958) Statistical Methods for Research Workers. 13th edition, revised. Oliver and Boyd, Edinburgh.

Green, D. H. and Ringwood, A. E. (1967) The genesis of basaltic magmas. Contrib. Mineral. Petrol., 15.

Gorbatschev, R. (1961) Dolerites of the Eskilstuna Region. Sveriges Geol. Unders., Ser. C., No. 580.

GunN, B. (1966) Modal and element variation in Antarctic Tholeites. Geoch. et Cosmochim. Acta, 30, No. 9.

Hamilton, W. (1965) Diabase sheets of the Taylor Glacier Region, Victoria Land, Antarctica. U. S. Geological Survey Professional Paper 456-B.

Jamieson, B. G. (1969) The Petrology of olivine-rich basaltic rocks, Nuanetsi, Rhodesia. Unpublished $\mathrm{Ph}$. D. Thesis, University of Edinburgh.

- (1970) Phase relations in some tholeiitic lavas illustrated by the system $\mathrm{R}_{2} \mathrm{O}_{3}-\mathrm{XO}-\mathrm{YO}-\mathrm{ZO}_{2}$. Mineralogical Magazine, 37, No. 289.

Kaнma, A. (1951) On the contact phenomena of the Satakunta diabase, Bull. Comm. Géol. Finlande, No. 152.

LAITAKARI, I. (1969) On the set of olivine diabase dikes in Häme, Finland. Bull. Comm. Géol. Finlande, No. 241.

Marmo, V. and Mikkola, T. (1963) On diabase dikes at Keuruu, Central Finland. Compt. Rend. Soc. Geol. Finlande, No. 35.

Mathias, M., Siebert, J. C., Rickwood, P. C. (1970) Some aspects of the Mineralogy and Petrology of
Ultramatic Xenoliths in Kimberlite. Contrib. Mineral. Petrol., 26.

Nockolds, S. R., and Allen, R. (1956) The geochemistry of some igneous rock series - III. Geoch. et Cosmochim. Acta, 9.

O'Hara M. J. (1965) Primary magmas and the origin of basalts. Scottish Journal of Geology, Vol. 1.

- (1968) The bearing of phase equilibria studies in synthetic and natural systems on the origin and evolution of basic and ultrabasic rocks. Earth Science Reviews, Volume 4.

- (1970) Upper Mantle composition inferred from laboratory experiments and observations of volcanic products. Physics of the Earth and Planetary Interiors, 3.

PANkhurst, R. J. (1969) Strontium Isotope Studies related to Petrogenesis in the Caledonian Basic Igneous Province of NE Scotland. J. Petrol. 10, No. 1.

Philpotts, J. A. and Schneitzler, C. C. (1968) Europium anomalies and the genesis of basalt. Chem. Geol., Vol. 3.

- (1968) »Genesis of Continental Diabases and Oceanic Tholeites considered in light of Rare-earth and Barium abundances and Partition Coefficients» in Origin and Distribution of the Elements, edited by L. H. Ahrens. Pergamon Preas, Oxford.

- (1969) Phenocryst-matrix partition coefficients for $\mathrm{K}, \mathrm{Rb}, \mathrm{Sr}$, and $\mathrm{Ba}$ with applications to anorthosite and basalt genesis. Geoch. et Cosmochim. Acta, 34 .

Prinz, M. (1964) Geologic evolution of the Beartooth Mountains, Montana and Wyoming. Geol. Soc. Amer. Bull., 75.

Savolahtr, A. (1964) Olivine diabase dike of Ansio in Padasjoki, Finland. Bull. Comm. Géol. Finlande, No. 215.

Trlley, C. E., Yoder, H. S., Schairer, J. F. (1966) Melting relations of volcanic rock series. Ann. Report. Geophys. Lab., Carnegie Inst. Yearbook 65, pp. $260-9$.

Turner, F. J. and Verhoogan, J. (1960) Igneous and Metamorphic Petrology. Second edition. McGrawHill Book Co., Inc. N.Y.

WALKER, F. (1953) The pegmatitic differentiates of basic sheets. Amer. J. Sci., 251.

Walker, K. R. (1969) The Palisades Sill, New Jersey: A Reinvestigation. Geol. Soc. America, Special Paper 111.

Weigand, P. W. and Ragland, P. C. (1970) Geochemistry of Mesozoic Dolerite Dikes from Eastern North America. Contrib. Mineral. Petrol., 29, No. 3.

Wright, T. and Doherty, P. (1970) A linear programming and least squares Computer Method for solving Petrologic Mixing Problems. Geol. Soc. Amer. Bull., 81.

Manuscript received, April 15, 1971. 